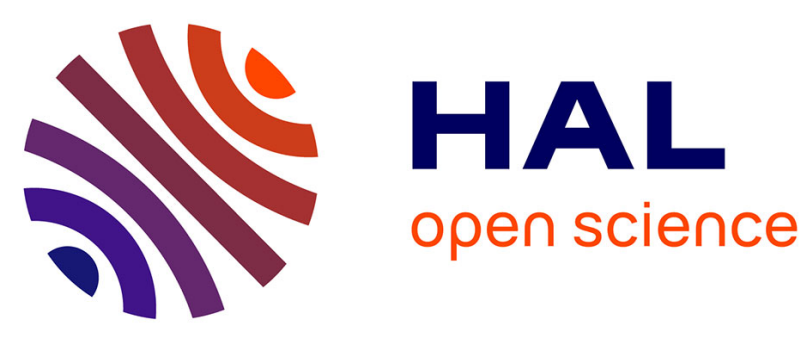

\title{
New Insights on Biodiversity and Conservation of Amphidromous Shrimps of the Indo-Pacific islands (Decapoda: Atyidae: Caridina)
}

V. de Mazancourt, W. Klotz, G. Marquet, B. Mos, D.C. Rogers, P. Keith

\section{- To cite this version:}

V. de Mazancourt, W. Klotz, G. Marquet, B. Mos, D.C. Rogers, et al.. New Insights on Biodiversity and Conservation of Amphidromous Shrimps of the Indo-Pacific islands (Decapoda: Atyidae: Caridina). Recent Advances in Freshwater Crustacean Biodiversity and Conservation, 1, CRC Press, pp.381-404, 2021, 10.1201/9781003139560-12 . hal-03303267

\section{HAL Id: hal-03303267 \\ https://hal.science/hal-03303267}

Submitted on 28 Jul 2021

HAL is a multi-disciplinary open access archive for the deposit and dissemination of scientific research documents, whether they are published or not. The documents may come from teaching and research institutions in France or abroad, or from public or private research centers.
L'archive ouverte pluridisciplinaire $\mathbf{H A L}$, est destinée au dépôt et à la diffusion de documents scientifiques de niveau recherche, publiés ou non, émanant des établissements d'enseignement et de recherche français ou étrangers, des laboratoires publics ou privés. 
1 CHAPTER 11: New insights on biodiversity and conservation of amphidromous shrimps of the Indo-Pacific islands (Decapoda: Atyidae: Caridina).

de Mazancourt V., ${ }^{1}$ Klotz W., ${ }^{2}$ Marquet G., ${ }^{1}$ Mos B., ${ }^{3}$ Rogers D.C., ${ }^{4}$ \& Keith P. ${ }^{1}$

\section{Abstract}

Amphidromous shrimps of the genus Caridina (Crustacea: Decapoda: Atyidae) are essential components of the tropical insular freshwater ecosystems. Due to an extremely confused taxonomy, their biodiversity is poorly known, and their conservation status cannot be properly assessed. However, thanks to recent advances of integrative taxonomy, the systematics of this genus progressively becomes clearer, allowing us to draw conclusions about their biogeography and conservation biology. In this chapter, we 1) review the current state of knowledge of amphidromous Caridina diversity in the light of the latest results of integrative taxonomy on this model, 2) review the threats faced by Caridina in Indo-Pacific Islands, and 3) discuss how integrative taxonomy approaches can inform and support programs designed to limit the impacts of threatening processes on the diversity of Caridina. Finally, we provide recommendations for the conservation of these species and their habitats.

\subsection{Introduction}

Atyid shrimps (Crustacea: Decapoda) are essential components of tropical freshwater ecosystems, 24 playing a role of cleaner by shredding fallen leaves or filtering organic particular matter and being preys to a number of organisms (Covich et al., 1999 ; Crowl et al., 2001). Among them, genus Caridina H. Milne Edwards, 1837 is particularly diversified, comprising more than 300 described species making it the most diversified of the infra-order Caridea (De Grave et al., 2015). In IndoPacific Islands, the majority of the species of Caridina have an original diadromous lifestyle, with a planktonic marine larval phase and a benthic freshwater adult phase; amphidromy (McDowall, 2007

30 ; Bauer, 2013). This strategy allows the species to colonize isolated habitats, such as the rivers of

31 volcanic islands, and to survive to the instability of these environments (floods, droughts, 32 volcanism, etc.) by keeping a stock of larvae in the ocean, ready to recolonize depopulated rivers 
33 (Keith et al., 2010). Amphidromy, by isolating populations, has also contributed to establishing the

34 high diversity that exists among caridean shrimps. This diversity, however, is the source of an extreme taxonomic confusion that impedes the monitoring of the species and the establishment of appropriate conservation programs (Klotz \& Rintelen, 2014). Recently, with the development of new molecular biology techniques, integrative taxonomy is being increasingly used by systematicians attempting to achieve more precise species delineations by combining morphological data with genetic, ecological and/or biogeographical information (Mazancourt et al., 2017). In this chapter, we 1) review the current state of knowledge of amphidromous Caridina diversity in the light of the latest results of integrative taxonomy on this model, 2) review the threats faced by Caridina in Indo-Pacific Islands, and 3) discuss how integrative taxonomy approaches can inform and support programs designed to limit the impacts of threatening processes on the diversity of Caridina.

\subsection{Biodiversity}

\subsubsection{Taxonomy}

There is substantial confusion surrounding the taxonomy of many species of Caridina that has resulted in the creation of several species complexes (N.B.: We consider a species complex a monophyletic species group that share a common taxonomic history in having been synonymized at one point, and/or that can be identified by morphological characters). In Indo-Pacific islands, amphidromous shrimps have been grouped into seven main complexes, (1) Caridina nilotica (P. Roux, 1833) complex (Johnson, 1963 ; Holthuis, 1978 ; Jalihal et al., 1984 ; Choy, 1991 ; Richard \& Clark, 2005 ; Karge \& Klotz, 2007), (2) C. weberi De Man, 1892 complex (Richard \& Chandran, 1994 ; Cai \& Shokita, 2006a), (3) C. gracilirostris De Man, 1892 complex (Cai \& Ng, 2001, 2007), (4) C. typus H. Milne Edwards, 1837 complex (Karge \& Klotz, 2007 ; Bernardes et al., 2017), (5) C. serratirostris De Man, 1892 complex (Cai \& Shokita, 2006b), (6) C. brevicarpalis De Man, 1892 complex (Short, 2009) and (7) C. propinqua De Man, 1908 complex (WK, unpublished). Little work has been done to differentiate among the species clustered within these complexes, possibly due to the difficulty and costs associated with genetic analyses and the highly similar morphology of shrimps from different populations.

62 To recognize amphidromous species, the egg size is often a good indicator. Small eggs indicate that 63 the species has an indirect development with several planktonic stages that are often marine.

64 Conversely, species with large eggs are most likely landlocked, with a direct development limiting 
their dispersal abilities, meaning that they are often endemic. However, some species can have small eggs and still be endemic. This can be due to particular conditions that limit the dispersal of marine larvae. For example, oceanic currents or physical barriers (e.g. closed coral lagoons) may prevent dispersal to nearby islands even if larvae are capable of surviving in oceanic conditions. It is not unusual therefore for different types of larval development to occur within one species group. Moreover, in some cases, like in C. meridionalis (see Mazancourt et al., 2018) or C. gracilipes (WK, unpublished), egg size varies within a single species, depending on the habitat, with generally larger eggs found in upstream localities and smaller eggs near the estuary, suggesting the possibility of facultative amphidromy.

\subsubsection{Phylogeny}

A recent work (Mazancourt et al., 2019), object of a presentation at the $9^{\text {th }}$ International Crustacean Congress in Washington DC (May 2018), focused on producing a molecular phylogeny of two species complexes from the Indo-Pacific islands, $C$. nilotica and $C$. weberi complexes. This work demonstrated the importance of an integrative taxonomy approach in understanding the diversity of Caridina. Non-integrated approaches are likely to underestimate the as the number of species for a locality, with many cryptic/pseudocryptic species confused under a single name, or more rarely, morphotypes of a single variable species described as separate species. As a result, geographical ranges and ecological data concerning poorly delineated species are often misleading, which impedes the establishment of programs that provide sufficient protection and management. The work also found that habitat was often the most important factor leading to the separation of complexes. Species belonging to different complexes live in different habitat types. Identification to species level (or at least species complex level) and monitoring of Caridina diversity over time may therefore provide an early warning system that provides information about changes in their environment.

\subsubsection{Habitat}

(Figure 1 here) 
Habitat is a critical factor influencing the distribution of Caridina species and it can often be used as an identification tool to separate species (Mazancourt et al., 2019). Caridina shrimps inhabit different kinds of freshwater ecosystems, divided between lentic environments, such as lakes $\left(\mathrm{n}^{\circ} 7\right.$ in Fig. 1; Fig. 2L) or swamps ( ${ }^{\circ} 8$ in Fig. 1; Fig. 2K), and lotic (river) environments for surface waters, as well as for subterranean waters ( $\mathrm{n}^{\circ} 9$ in Fig. 1). Amphidromous shrimps, due to their ability to migrate between freshwater and seawater are mainly found in rivers or lentic environments connected to the sea.

102 On the tropical mountainous islands that are typical in the Indo-Pacific, rivers are subject to important natural disturbances like droughts, floods, volcanic eruptions, or earthquakes. The flow of rivers can therefore be subject to great temporal variations (strong during floods or zero for temporary waterways) as well as spatial variations (depending on the slope, substrate type, or plant cover). The morphology of rivers, for example, plays an important role in determining the variability of environmental conditions that are often unique to the specific watershed that form discontinuous units isolated from each other by the sea and geological formations, such as ridgelines. The length of rivers depends on island morphology, ranging from short streams a few metres in length to large rivers of several kilometres. Examples of the great diversity of river lengths in the Indo-Pacific include the Diahot in New Caledonia and the Sigatoka in Fiji.

112 To better characterize the variable environmental conditions experienced by shrimp in different 113 rivers, Keith et al., (2010) proposed an altitudinal zonation divided into five zones with flexible 114 boundaries depending on the island studied. The five zones are the spring zone $\left(\mathrm{n}^{\circ} 1\right.$ in Fig. 1; Fig. 115 2I), the higher course ( ${ }^{\circ} 2$ in Fig. 1; Fig. 2A and B), the middle course ( ${ }^{\circ} 4$ in Fig. 1; Fig. $2 \mathrm{C}$ and 116 D), the low part of the stream ( $\mathrm{n}^{\circ} 5$ in Fig. 1; Fig. $2 \mathrm{E}$ and F), and the lower course $\left(\mathrm{n}^{\circ} 6\right.$ in Fig. 1; 117 Fig. 2G and H). An additional sub-zonation exists depending on the current velocity, distinguishing 118 calm zones (Fig. 2C and E) or pools (Fig. 2B) from riffles (Fig. 2A, D and F). Usually, the 119 altitudinal zonation is further simplified into three functional levels (Fig. 1):

120 - The higher course, characterized by a steep slope (generally $>10 \%$ ), a fast current and a boulder 121 substrate.

122 - The middle course, characterized by an intermediate slope $(<10 \%)$ and a substrate of pebbles and 123 rocks or sand in calm areas. This level is typically separated from the higher course by a 124 topographical feature, like a cascade ( ${ }^{\circ} 3$ in Fig. 1; Fig. 2J).

125 - The lower course, characterized by a very low or zero slope, with a slow current and a substrate of 126 pebbles whose size decreases when approaching the estuary. The estuary is the lowest end of the 
127 river where environmental conditions are influenced by the tidal flux of seawater, as distinguished 128 from the purely limnic area. This chemical boundary, between seawater and freshwater, is essential 129 in terms of habitat, for some amphidromous species. The size of the estuary can vary, from very 130 broad and long for large rivers (like the Jordan in Santo, Vanuatu) to absent in some small streams 131 flowing directly from the mountains to the sea.

132 Species living in rivers are subject to a range of biotic and abiotic conditions depending on the zone 133 of the river where they live. Differences in biotic and abiotic conditions often form gradients that 134 apply over the entire length of rivers (Tab. 1):

135 - A current velocity gradient mainly linked to elevation. Water currents are typically fastest at high 136 altitudes and slowest in the estuary, although local variations at a given altitude are also important, 137 depending on the configuration of the river (calm zones vs riffles).

138 - A temperature and oxygen gradient, with cool and oxygen-rich waters typical of the higher course 139 and warm and low-oxygen waters typical of the lower course.

140 - A width and depth gradient, from small rivulets in the spring zone to large rivers near the mouth.

141 - A salinity gradient that is typically limited to the lower course. Salinity tends to decline rapidly 142 outside of the areas influenced by tidal flux.

143 - A sediment size gradient, from bedrock in the spring zone, to boulders and rocks in the higher 144 course, pebbles in the middle course, and sand and silt in the lower course.

145 - A particulate organic matter gradient, with clear, oligotrophic waters in the spring area to turbid, 146 eutrophic waters in the estuary.

147 - A riparian vegetation gradient, with riverbanks consisting of naked rock in the higher course 148 switching to dense riparian vegetation in the lower course.

149 - A predation gradient, with the greatest density and diversity of predatory species (birds, fish) 150 present in the lower course. Predators of shrimp in the higher course are mostly limited to eels 151 (Anguilla spp.) or insects (dragonfly larvae, etc.) 
155 Gradients in abiotic and biotic factors along rivers overlap in many combinations to create a 156 considerable variety of micro-habitats (Gehrke et al., 2011) to which species of Caridina have 157 adapted. We can observe a vertical zonation of species depending on the variation of these factors 158 linked to the elevation, as well as horizontal variables linked to the river configuration, according to 159 the lotic or lentic facies in the area, or micro-habitats (sunken wood, roots, aquatic macrophytes, 160 rocks, etc.). Indeed, different species assemblages are observed at the different levels of the rivers 161 and in the different flowing facies. In the lower course will be encountered species of the C. nilotica 162 species complex (Mazancourt et al., 2018), the $C$. gracilirostris species complex or species allied to 163 C. serratirostris and C. brevicarpalis. Higher in the river, two species groups are found, C. weberi 164 complex in lotic areas and C. nilotica complex in lentic areas. Species of the C. typus group seem to have a broader range of habitats, present virtually in the whole length of the rivers (pers. obs.).

166 As observed for fish in tropical rivers by Pouilly et al. (2006) and Lorion et al. (2011) in continental 167 systems and by Keith et al. (2015) in insular systems, there seems to be an altitudinal diversity gradient in Caridina, with a maximum diversity in the lower course, decreasing with elevation. This diversity gradient may be explained by the greater concentration of organic particulate matter in the lower reaches, allowing the establishment of a higher biomass (Angermeier \& Karr, 1983). Alternatively, diversification may be promoted by higher heterogeneity in habitats (Gorman \& Karr, 1978) and stronger predator pressure in the lower course (Deacon et al., 2018). The proximity to the ocean of the lower course also presents the advantage of reducing the distance that larvae of amphidromous species have to travel to the sea as larvae and to the upper course as juveniles. In higher altitudes, in contrast, resources are more limited but predator pressure is weaker, which often leads to low biodiversity but high abundance (Leberer \& Nelson, 2001). Some species living in these environments have adopted a life cycle completed entirely in freshwater, with reduced larval stages or even direct development, avoiding the hazards of migration (Hancock, 1998).

It is important to note patterns in diversity across zones can sometimes be more nuanced than the zonation framework proposed by Keith et al. (2010) may suggest. In some cases, patterns in 182 Caledonia, ultramafic rocks of the South of the island leach high concentrations of metals (nickel, 183 chromium, cobalt) into the water of the rivers. These metals are toxic for most species, but some 184 species that have evolved to tolerate high levels of dissolved metals live there (Marquet et al., 2003). These rivers flowing over ultramafic substrate thus exhibit a different fauna than rivers on sedimentary substrate, with different altitudinal zonations. 


\subsubsection{Biogeography}

191 The genus Caridina can be found in virtually all the rivers of the tropical Indo-Pacific and Africa, 192 ranging from West Africa (Richard \& Clark, 2009), Egypt (Hussein \& Obuid-Allah, 1990; Richard 193 \& Clark, 2005; Mazancourt et al., in press) and South Africa (Mirimin et al., 2015) to mainland 194 Japan (Saito et al., 2012), Polynesia (Keith et al., 2013) and South Australia (Davie, 2002), 195 stretching to Middle East localities (Christodoulou et al., 2016) (Fig. 3).

(Figure 3 here)

As expected for such a wide-ranging genus, regional differences in diversity of Caridina exist in the Indo-Pacific. When focusing on endemic species of Caridina (Fig. 4A), the maximum diversity occurs around the Coral Triangle (Veron et al., 2009), between the Philippines, Indonesia, and Papua-New Guinea. The number of endemic species tends to be substantially lower in rivers further away from this area, although large continental islands such as Madagascar or Sri Lanka, and archipelagos such as the Solomon Islands, constitute local hotspots of endemism. Some of these 205 hotspots have been exposed by previous studies on freshwater shrimps, including Madagascar (De Grave et al., 2008; De Grave et al., 2015; Cumberlidge et al., 2017) and Sulawesi (De Grave et al., 2008; Klotz \& Rintelen, 2013; De Grave et al., 2015). Islands of relatively old geological origin like New Caledonia, Fiji, or Mauritius also appear to harbor a high diversity of endemic species. In contrast, younger and often isolated islands like those of Polynesia or Micronesia harbor fewer endemic species. Localities at the northern and southern limits of the distribution area (Japan and

211 South Australia for example) show low endemism.

(Figure 4 here)

215 It appears regional patterns in the diversity in Caridina of the Indo-Pacific are explained by the age, 216 size, and latitude of islands. Diversity will likely be high in a large continental island close to the 
equator and low in a small young volcanic island or in an area away from the equator (Paulay, 1994

218 ; Willig et al., 2003). Geologically old islands have had more opportunity to be colonized by

219 shrimps, and had time for colonizers to adapt and specialize to the different habitats and form new

220 species. Chen \& He (2009) showed that the number of speciations in islands, and thus their

221 biodiversity, increases with time, whereas the number of colonizations decreases. According to the

222 same study, the number of endemic species correlates to the size of the island, due to the greater

223 diversity of habitats (geological or climatic differences, for example), which agrees with our

224 observations for large islands such as Madagascar, Sri Lanka, or New Caledonia.

225 The patterns in the diversity of endemic species (Fig. 4C) vary considerably from the patterns in the 226 diversity of amphidromous species (Fig. 4A). The greatest diversity of amphidromous species is 227 found in the Solomon Islands and Vanuatu. This may also include the Coral Triangle, as the 228 diversity of Caridina from the area remains poorly known. The high diversity of Caridina in this 229 region may be explained by the complex geological history of the area, which lies at the 230 convergence of three tectonic plates. The region contains islands of both continental and volcanic 231 origin, as well as historical connections to Papua in the North.

232 The lowest diversity of amphidromous species is found in Polynesia and at the borders of the 233 distribution area in general (Fig. 4C). Important areas of endemism, such as Madagascar, are not 234 hotspots of diversity for amphidromous species. Localities with low endemism, like the Polynesian 235 or Micronesian islands, often have a higher proportion of amphidromous species.

236 Patterns in the diversity of amphidromous species may be explained by the recent colonization of 237 the islands by amphidromous shrimps with great dispersal abilities, allowing them to colonize these 238 isolated habitats without becoming reproductively isolated. Small islands often exhibit unstable 239 conditions in which endemic landlocked populations could not maintain themselves. In contrast, 240 amphidromous species can repopulate islands following disturbance as they maintain a stock of 241 larvae in the ocean, ready to recolonize depopulated habitats (McDowall, 2007).

242 The landlocked or amphidromous lifestyle of a species is not always linked to it being endemic or 243 widespread, with examples of amphidromous species that are known from a single island for 244 instance. The patterns of diversity of landlocked species are shown in Fig. 4B. Globally, the highest 245 diversity of landlocked species is found in the Coral Triangle with a diminution when one moves 246 away from it, until they completely disappear at the borders of the distribution area of the genus. 247 However, the differences between landlocked and endemic or amphidromous species is that 248 landlocked species are mainly absent from volcanic islands such as Polynesia, Micronesia, Solomon 
Islands, or Vanuatu, where the majority of species are amphidromous. In contrast landlocked species often constitute the majority of the species in continents (India, China, Australia, South Africa) or large continental islands (Madagascar). This supposes that habitats for landlocked species need to have been available for sufficient time for new species to evolve a landlocked lifestyle from amphidromous ancestors, or for species to diverge from landlocked ancestors that were already present.

\subsection{Conservation}

Taxonomic confusion was until now a substantial obstacle to the establishment of programs aimed at the conservation of species of Caridina. Some ill-delineated species like $C$. longirostris or $C$. weberi were thought to be widespread, however, studies using an integrative taxonomy approach (Mazancourt et al., 2018) showed that these 'species' are actually comprised of several species with more restricted distributions (some even being endemic). Furthermore, a better knowledge of systematics allows greater understanding of the habitat and ecology of these species, since each species is adapted to a different environment. These new data will impact the way in which the conservation status of these species is assessed. Species with small distributions and specific habitat needs are more vulnerable to extinction than widespread and tolerant species (Purvis et al., 2000).

\subsubsection{Threats to amphidromous Caridina}

The main threats faced by Caridina almost always originate from anthropization of their environment.

Habitat degradation. Many anthropic activities induce habitat degradation. The direct impacts of habitat degradation occur through impact through pollution of the rivers by pesticides (Kumar et al., 2010a ; Kumar et al., 2010b), industrial accidents (Dominique, 2014), illegal poisoning (Greathouse et al., 2005), use of the rivers as dumps (Keith et al., 2006), eutrophication by fertilizers, poisoning and causing the proliferation of algae clogging the rivers, or increased sedimentation from mining, gravel extraction, or constructions (dams, roads, etc.) smothering the stream bed, and increasing water turbidity (Boseto et al., 2007; Keith et al., 2013). Habitat destruction also occurs through the removal of water from river systems for agriculture, industry or tourism, causing physical changes (e.g. lower flow rates) and the disappearance of lotic zones (Keith et al., 2013) that are the exclusive habitat of some species (e.g. Caridina weberi species complex). The cause and effects of 
280 habitat destruction can also be associated with human activities that do not impact rivers directly 281 but have flow-on effects that impact shrimp habitats and threaten the viability of populations (i.e. indirect effects). For example, the disappearance of perennial rivers and associated loss of habitat for shrimp due to deforestation, like in Rodrigues Island (Keith et al., 2006), in Madagascar for rosewood, in Anjouan (Mirhani et al., 2014) for firewood and Ylang-ylang plantations, in the Marquesas islands and Rapa for goats and livestock, or in New Caledonia due to bushfires. As some species of amphidromous shrimps live in mangroves (like those of the C. gracilirostris complex), they are threatened during both their larval and adult stages by the degradation of their habitat by aquaculture activities. Together, the impacts of aquatic and terrestrial habitat destruction are well documented to affect the physiology, reproduction and migration of caridean shrimp and remain one of the most important threatening processes for carideans and other freshwater species (De Grave et al. 2015).

Reduced connectivity. The construction of instream barriers suppresses habitat connectivity (Dudgeon, 2000 ; March et al., 2003). The construction of dams, such as the Yate hydroelectric plant in New Caledonia, are one such example of instream barriers that result in a rapid disappearance of amphidromous species in the whole watershed upstream. Indeed, shrimps need to be able to migrate along the river course depending on the water level in order to not get trapped in pools during the dry season. For amphidromous species, it is critical to have a continuum between the adult habitat and the sea in order to maintain populations.

Introduced species. The introduction of exotic species can lead to local extinctions of indigenous species due to predation, competition, habitat alteration, or disease transmission (Keith, 2002a, 2002b; De Grave et al., 2015). For caridean shrimp, another important but little studied threat associated with introduced species, is the potential for hybridization with non-native caridean species. The ease with which caridean shrimp hybridize is well noted in the aquarium literature. There have been no reports of hybridization of introduced and native carideans in the wild, but the extinction of local populations due to hybridization following a translocation within a catchment has already occurred in other genera within the family Atyidae (Hughes et al., 2003; Fawcett et al., 2010).

Overharvesting. Shrimps are harvested for human consumption. In the Philippines, Madagascar, Indonesia, India, and China, caridean shrimp are caught using nets in large quantities to be eaten fresh, dried, or salted, and to feed animals or used as fertilizer (Holthuis, 1980), or in Reunion 311 Island where they are called "chevaquines" (GM, pers. comm.). A unique threat for Caridina spp. is the capture of individuals for the aquarium trade, particularly for the colorful species living in 
313 Sulawesi (De Grave et al., 2015) or "Bee shrimps" from mainland China, some species being 314 known only from a single stream of about 150m in length (WK pers. comm.). While most of the species impacted are lacustrine landlocked, in the future growing global demand could see the expansion of the collection of amphidromous species. Currently, only a few amphidromous species appear in the trade, but whether these are collected legally, poached, or bred in captivity is difficult to determine due to long and complex supply chains. It is unclear how many shrimp are traded globally, but there is substantial anecdotal evidence suggesting local populations experience severe declines due over-collection, particularly where a local colour or pattern variant becomes highly sort after in the trade. For example, Klotz \& Lukhaup (2014) reported the disappearance of Caridina trifascata from locales near Zuhai, China over a period of less than 12 months, likely associated with over-harvesting for the aquarium trade.

Climate change. Climate change is likely already impacting and will continue to impact caridean shrimp through a variety of direct and indirect mechanisms (Table 1). Unfortunately, whilst crustaceans generally appear to be robust to some changes in their environment associated with climate change (e.g. ocean acidification), little research has been done to address the gaps in our knowledge about indirect effects of climate stressors, and the effects of interactions of climate stressors (e.g. temperature) with non-climate stressors (e.g. pesticide pollution). This is concerning given studies that have examined the indirect and interactive effects of climate stressors on marine taxa have highlighted how these effects may be more important than the direct effects of climate stressors (e.g. Kamya et al., 2017; Rosenblatt \& Schmitz, 2016; Kroeker et al., 2012; Boyd \&

\subsubsection{Conclusions and recommendations}

338 The integrative study of Caridina led to the discovery of unsuspected diversity in Indo-Pacific

339 Islands, with species complexes that are now recognized and present differences in habitat.

340 Therefore, when making inventories of the freshwater fauna of rivers, if it is not possible to identify 341 specimens to species level, the species complex can be sufficient to provide interesting data. Keys and diagnoses of the different species complexes will be presented in an upcoming study

343 (Mazancourt et al. submitted). Now that species are better delineated thanks to integrative 
taxonomy, their distribution (including micro and macro-habitats) can be more informative and their specific conservation status (threats, IUCN status, etc.) needs to be re-assessed.

346 Our recommendations to protect these amphidromous species of Caridina revolve around three 347 main points:

348 1) Taking biological and ecological specificities into consideration

Arguably the best way to enable conservation is by changing the mind-set of people directly implicated through education and example. For example, managing caridean species requires managers to have a minimum knowledge of their biology (i.e. amphidromous lifecycle) and to take their specificities into consideration when making decisions. Understanding of the lifecycles of amphidromous species highlights the importance of maintaining the natural flow of water ways in a good state. Maintaining population connectivity through natural water flows allows populations to be comprised of a range of life stages. This limits the potential for local or regional extinctions as breeding populations depend on the pool of larvae to replace them (and conversely, the pool of larvae depends on the breeding populations). Successful implementation of conservation measures designed to maintain and enhance natural water flows may be best achieved through the inclusion of a range of stakeholders in projects (e.g. farmers, fishers, water management authorities, local government, community conservation groups, international conservation organisations, etc.).

The most efficient way to protect amphidromous species is to protect their environment by limiting anthropic impacts. This requires an integrated management approach that takes into account the role of both terrestrial and aquatic impacts. For example, water catchments should always have a minimum flow in line with their natural seasonal variations, considering the upstream migration of the juveniles is often triggered by greater freshwater arrival in the sea during floods. Therefore the effects of a variety of management decisions, such as avoiding man-made structures altering water flow, design of roads and dams that maintain the connectivity from the sea to the mountains, maintaining riparian vegetation in a good state, and 
2) Establishing priorities for species conservation

375

376

As conservation status is not known for many species, the priority is to protect their habitats. It would thus be useful to identify those habitats that need special protection and make sure to apply to them the recommendations of the previous point. Caridean shrimps seem to be good indicators of water and habitat quality. They could thus be a very useful tool for managers as indicators of anthropic effects and the impact of climate change in tropical rivers. As exotic species are often harmful to native fauna, preventing their introduction would be an important recommendation to preserve freshwater shrimps. Finally, supporting research on the biology and ecology of these species would help to improve our knowledge and assess the threats they face.

\section{References}

Angermeier, P. L. \& Karr, J. R. (1983) Fish communities along environmental gradients in a system of tropical streams. Environmental Biology of Fishes, 9(2): 117-135.

Bauer, R. T. (2013) Amphidromy in shrimps: a life cycle between rivers and the sea. Latin American Journal of Aquatic Research, 41(4): 633-650.

Beaugrand, G. \& Kirby, R. R. (2018) How do marine pelagic species respond to climate change? Theories and observations. Annual Review of Marine Science, 10: 169-197.

Bernardes, S. C., Pepato, A. R., Rintelen (von), T., Rintelen (von), K., Page, T. J., Freitag, H. \& de Bruyn, M. (2017) The complex evolutionary history and phylogeography of Caridina typus (Crustacea: Decapoda): long-distance dispersal and cryptic allopatric species. Scientific Reports, 7(1): 9044.

Boseto, D., Morrison, C., Pikacha, P. \& Pitakia, T. (2007) Biodiversity and conservation of freshwater fishes in selected rivers on Choiseul Island, Solomon Islands. The South Pacific Journal of Natural Science, 3(1): 16-21.

Boyd, P. W. \& Brown, C. J. (2015) Modes of interactions between environmental drivers and marine biota. Frontiers in Marine Sciences, 2(9): 1-7.

Breitburg, D., Levin, L. A., Oschlies, A., Grégoire, M., Chavez, F. P., Conley, D. J., Garçon, V., Gilbert, D., Gutiérrez, D., Isensee, K., Jacinto, G. S., Limburg, K. E., Montes, I., Naqvi, S. W. A., Pitcher, G. C., Rabalais, N. N., Roman, M. R., Rose, K. A., Seibel, B. A., 
Telszewski, M., Yasuhara, M. \& Zhang, J. (2018) Declining oxygen in the global ocean and coastal waters. Science, 359(6371): eaam7240.

Cai, W., Wang, G., Dewitte, B., Wu, L., Santoso, A., Takahashi, K., Yang, Y., Carréric, A. \& McPhaden, M. J. (2018) Increased variability of eastern Pacific El Niño under greenhouse warming. Nature, 564(7735): 201-206.

Cai, Y. \& Ng, P. K. L. (2001) The freshwater decapod crustaceans of Halmahera, Indonesia. Journal of Crustacean Biology, 21(3): 665-695.

Cai, Y. \& Ng, P. K. L. (2007) A revision of the Caridina gracilirostris De Man, 1892, species group, with descriptions of two new taxa (Decapoda; Caridea; Atyidae). Journal of Natural History, 41((25-28)): 1585-1602.

Cai, Y. \& Shokita, S. (2006a) Atyid shrimps (Crustacea: Decapoda: Caridea) of the Ryukyu Islands, southern Japan, with descriptions of two new species. Journal of Natural History, 40(3840): 2123-2172.

Cai, Y. \& Shokita, S. (2006b) Report on a collection of freshwater shrimps (Crustacea: Decapoda: Caridea) from the Philippines, with descriptions of four new species. The Raffles Bulletin of Zoology, 54(2): 245-270.

Chen, X.-Y. \& He, F. (2009) Speciation and endemism under the model of island biogeography. Ecology, 90(1): 39-45.

Choy, S. C. (1991) The atyid shrimps of Fiji with description of a new species. Zoologische Mededelingen, 65(27): 343-362.

Christodoulou, M., Anastasiadou, C., Jugovic, J. \& Tzomos, T. (2016) Freshwater Shrimps (Atyidae, Palaemonidae, Typhlocarididae) in the Broader Mediterranean Region: Distribution, Life Strategies, Threats, Conservation Challenges and Taxonomic Issues. In: T. Kawai \& N. Cumberlidge (Eds), A Global Overview of the Conservation of Freshwater Decapod Crustaceans. Springer, Cham, pp. 199-236.

Comte, L. \& Grenouillet, G. (2013) Do stream fish track climate change? Assessing distribution shifts in recent decades. Ecography, 36: 1236-1246.

Covich, A. P., Palmer, M. A. \& Crowl, T. A. (1999) The role of benthic invertebrate species in freshwater ecosystems. BioScience, 49: 119-128.

Crowl, T. A., McDowell, W. H., Covich, A. P. \& Johnson, S. L. (2001) Freshwater shrimp effects on detrital processing and nutrients in a tropical headwater stream. Ecology, 82(3): 775-783.

Cumberlidge, N., Rasamy Razanabolana, J., Ranaivoson, C. H., Randrianasolo, H. H., Sayer, C., Máiz-Tomé, L., Van Damme, D. \& Darwall, W. R. T. (2017) Updated extinction risk 
assessments of Madagascar's freshwater decapod crustaceans reveal fewer threatened species but more Data Deficient species. Malagasy Nature, 12: 32-41.

Davie, P. J. F. (2002) Crustacea: Malacostraca: Phyllocarida, Hoplocarida, Eucarida (Part 1). In: A. Wells \& W. W. K. Houston (Eds), Zoological Catalogue of Australia. CSIRO Publishing, Australia, Melbourne, p. 551.

De Grave, S., Cai, Y. \& Anker, A. (2008) Global diversity of shrimps (Crustacea: Decapoda: Caridea) in freshwater. Freshwater Animal Diversity Assessment, 595: 287-293.

De Grave, S., Smith, K. G., Adeler, N. A., Allen, D. J., Alvarez, F., Anker, A., et al. (2015) Dead Shrimp Blues: A Global Assessment of Extinction Risk in Freshwater Shrimps(Crustacea: Decapoda: Caridea). PLoS ONE, 10(3): e0120198.

Deacon, A. E., Jones, F. A. M. \& Magurran, A. E. (2018) Gradients in predation risk in a tropical river system. Current Zoology, 64(2): 213-221.

Dominique, Y. (2014) Constat de pollution suite à un déversement d'effluent industriel au sein du creek de la Baie Nord. In. Oeil, Nouméa, New Caledonia, pp. 1-35.

Dudgeon, D. (2000) Large-Scale Hydrological Changes in Tropical Asia: Prospects for Riverine Biodiversity: The construction of large dams will have an impact on the biodiversity of tropical Asian rivers and their associated wetlands. BioScience, 50(9): 793-806.

Fawcett, J. H., Hurwood, D. A. \& Hughes, J. M. (2010) Consequences of a translocation between two divergent lineages of the Paratya australiensis (Decapoda:Atyidae) complex: reproductive success and relative fitness. Journal of the North American Benthological Society, 29(3): 1170-1180.

Ficke, A. D., Myrick, C. A. \& Hansen, L. J. (2007) Potential impacts of global climate change on freshwater fisheries. Reviews in Fish Biology and Fisheries, 17(4): 581-613.

Gehrke, P. C., Sheaves, M. J., Boseto, D. T., Figa, B. S. \& Wani, J. (2011) Chapter 7: Vulnerability of freshwater and estuarine fish habitats in the tropical Pacific to climate change. In: J. D. Bell, J. E. Johnson \& A. J. Hobday (Eds), Vulnerability of tropical Pacific fisheries and aquaculture to climate change. Secretariat of the Pacific Community, Auckland, New Zealand, pp. 369-431.

Gorman, O. T. \& Karr, J. R. (1978) Habitat Structure and Stream Fish Communities. Ecology, 59(3): 507-515.

Greathouse, E. A., March, J. G. \& Pringle, C. M. (2005) Recovery of a tropical stream after a harvest-related chlorine poisoning event. Freshwater Biology, 50(4): 603-615. 
Hancock, M. A. (1998) The relationship between egg size and embryonic and larval development in the freshwater shrimp Paratya australiensis Kemp (Decapoda: Atyidae). Freshwater Biology, 39(4): 715-723.

Hays, G. C., Richardson, A. J. \& Robinson, C. (2005) Climate change and marine plankton. Trends in Ecology and Evolution, 20: 337-344.

Holthuis, L. B. (1978) A collection of Decapod Crustacea from Sumba, Lesser Sunda islands, Indonesia. Zoologische Verhandelingen, 162: 1-55.

Holthuis, L. B. (1980) FAO species catalogue. Volume 1-Shrimps and prawns of the world (An annotated catalogue of species of interest to fisheries Vol. 1). Food and Agriculture Organization of the United Nations, Rome, Italy (271p).

Hughes, J. M., Goudkamp, K., Hurwood, D. A., Hancock, M. A. \& Bunn, S. (2003) Translocation causes extinction of a local population of the freshwater shrimp Paratya australiensis. Conservation Biology, 17(4): 1007-1012.

Hussein, M. A. \& Obuid-Allah, A. H. (1990) External morphology of the freshwater prawn Caridina africana collected from Egypt. Zoology in the Middle East, 4(1): 71-84.

Jackson, M. C., Loewen, C. J., Vinebrooke, R. D. \& Chimimba, C. T. (2016) Net effects of multiple stressors in freshwater ecosystems: a meta-analysis. Global Change Biology, 22(1): 180189.

Jalihal, D. R., Shenoy, S. \& Sankolli, K. N. (1984) Five new species of freshwater atyid shrimps of the genus Caridina H. Milne Edwards from Dharwar area (Karnataka State, India). Records of the Zoological Survey of India. Miscellaneous Publication, Occasional Paper, 69: 1-40.

Johnson, D. S. (1963) Distributional and other notes on some freshwater prawns (Atyidae and Palaemonidae) mainly from the Indo-West Pacific region. Bulletin of the National Museum of Singapore, 32: 5-30.

Kamya, P. Z., Byrne, M., Mos, B., Hall, L. \& Dworjanyn, S. A. (2017) Indirect effects of ocean acidification drive feeding and growth of juvenile crown-of-thorns starfish Acanthaster planci. Proceedings of the Royal Society of London Series B: Biological Sciences, 284(1856): 20170778.

Karge, A. \& Klotz, W. (2007) Süßwassergarnelen aus aller Welt. Dähne Verlag (198p).

Keith, P. (2002a) Freshwater fish and decapod crustacean populations on Reunion Island, with an assessment of species introductions. Bulletin Français de la Pêche et de la Pisciculture, 364: 97-107.

Keith, P. (2002b) Introduction of freshwater fishes and decapod crustaceans in French Polynesia, a review. Bulletin Français de la Pêche et de la Pisciculture, 364: 147-160. 
Keith, P., Lord, C. \& Maeda, K. (2015) Indo-Pacific Sicydiine Gobies: biodiversity, life traits and conservation. Société Française d'Ichtyologie, Paris (256p).

Keith, P., Marquet, G., Gerbeaux, P., Vigneux, E. \& Lord, C. (2013) Poissons et crustacés d'eau douce de Polynésie. Société Française d'Ichtyologie, Paris (282p).

Keith, P., Marquet, G., Lord, C., Kalfatak, D. \& Vigneux, E. (2010) Vanuatu freshwater fish and crustaceans. Société Française d'Ichtyologie, Paris (254p).

Keith, P., Marquet, G., Valade, P., Bosc, P. \& Vigneux, E. (2006) Atlas des poissons et des crustacés d'eau douce des Comores, Mascareignes et Seychelles (Collection Patrimoines naturels Vol. 65). MNHN, Paris, France (250p).

Klotz, W. \& Lukhaup, C. (2014) Breeders'n'Keepers Wildshrimp China Special. Dennerle GmbH, Vinningen, Germany (122p).

Klotz, W. \& Rintelen (von), K. (2013) Three new species of Caridina (Decapoda: Atyidae) from Central Sulawesi and Buton Island, Indonesia, and a checklist of the islands' endemic species. . Zootaxa, 3664(4): 554-570.

Klotz, W. \& Rintelen (von), T. (2014) To "bee" or not to be - on some ornamental shrimp from Guangdong Province, Southern China and Hong Kong SAR, with descriptions of three new species. Zootaxa, 3889(2): 151-184.

Kroeker, K. J., Kordas, R. L., Crim, R., Hendriks, I. E., Ramajo, L., Singh, G. S., Duarte, C. M. \& Gattuso, J.-P. (2013) Impacts of ocean acidification on marine organisms: quantifying sensitivities and interaction with warming. Global Change Biology, 19(6): 1884-1896.

Kroeker, K. J., Micheli, F. \& Gambi, M. C. (2012) Ocean acidification causes ecosystem shifts via altered competitive interactions. Nature Climate Change, 3: 156-159.

Kumar, A., Doan, H., Barnes, M., Chapman, J. C. \& Kookana, R. S. (2010a) Response and recovery of acetylcholinesterase activity in freshwater shrimp, Paratya australiensis (Decapoda: Atyidae) exposed to selected anti-cholinesterase insecticides. Ecotoxicology and Environmental Safety, 73(7): 1503-1510.

Kumar, A., R., C., Grocke, S. \& Bajet, C. (2010b) Toxicity of selected pesticides to freshwater shrimp, Paratya australiensis (Decapoda: Atyidae): Use of time series acute toxicity data to predict chronic lethality. Ecotoxicology and Environmental Safety, 73(3): 360-369.

Leberer, T. \& Nelson, S. G. (2001) Factors affecting the distribution of atyid shrimps in two tropical insular rivers. Pacific Science, 55: 389-398.

Lorion, C. M., Kennedy, B. P. \& Braatne, J. H. (2011) Altitudinal gradients in stream fish diversity and the prevalence of diadromy in the Sixaola River basin, Costa Rica. Environmental Biology of Fishes, 91(4): 487-499. 
Lough, J. M., Meehl, G. A. \& Salinger, M. J. (2011) Chapter 2: Observed and projected changes in surface climate of the tropical Pacific. In: J. D. Bell, J. E. Johnson \& A. J. Hobday (Eds), Vulnerability of Tropical Pacific Fisheries and Aquaculture to Climate Change. Secretariat of the Pacific Community, Auckland, New Zealand, pp. 49-99.

March, J. G., Benstead, J. P., Pringle, C. M. \& Scatena, F. N. (2003) Damming Tropical Islands Streams: Problems, Solutions and Alternatives. BioScience, 53(11): 1069-1078.

Marquet, G., Keith, P. \& Vigneux, E. (2003) Atlas des poissons et des crustacés d'eau douce de Nouvelle-Calédonie (Collection Patrimoines naturels Vol. 58). MNHN, Paris, France (288p).

Mazancourt (de), V., Klotz, W., Marquet, G. \& Keith, P. (2018) Integrative taxonomy helps separate four species of freshwater shrimps commonly overlooked as Caridina longirostris (Crustacea: Decapoda: Atyidae) in Indo-West Pacific islands. Invertebrate Systematics, 32(6): 1422-1447.

Mazancourt (de), V., Klotz, W., Marquet, G., Mos, B., Rogers, D. C. \& Keith, P. (2019) The complex study of complexes: The first well-supported phylogeny of two species complexes within genus Caridina (Decapoda: Caridea: Atyidae) sheds light on evolution, biogeography, and habitat. Molecular Phylogenetics and Evolution, 131: 164-180.

Mazancourt (de), V., Marquet, G., Klotz, W., Keith, P. \& Castelin, M. (2017) When morphology and molecules work together: lines of evidence for the validity of Caridina buehleri Roux, 1934 (Crustacea: Decapoda: Atyidae) and Caridina gueryi Marquet, Keith \& Kalfatak, 2009 as its junior synonym. Invertebrate Systematics, 31: 220-230.

McDowall, R. (2007) On amphidromy, a distinct form of diadromy in aquatic organisms. Fish and Fisheries, 8(1): 1-13.

Mcleod, E., Poulter, B., Hinkel, J., Reyes, E. \& Salm, R. (2010) Sea-level rise impact models and environmental conservation: A review of models and their applications. Ocean \& Coastal Management, 53(9): 507-517.

Mirhani, N., Taïbi, A. N., Ballouche, A. \& Razakamanana, T. (2014) De la problématique de l'eau au modèle numérique d'aménagement en milieu tropical humide insulaire : le bassin versant d'Ouzini-Ajaho (Anjouan - Comores). In: A. Ballouche (Ed), Eau, milieux et aménagement. Une recherche au service des territoires. Presses Universitaires d'Angers, pp. 117-134.

Mirimin, L., Kitchin, N., Impson, D. N., Clark, P. F., Richard, J., Daniels, S. R. \& Roodt-Wilding, R. (2015) Genetic and morphological characterization of freshwater shrimps (Caridina africana Kingsley, 1882) reveals the presence of alien shrimps in the Cape Floristic Region, South Africa. Journal of Heredity, 106(6): 711-718. 
Mos, B., Ahyong, S. T., Burnes, C. N., Davie, P. J. F. \& McCormack, R. B. (2017) Range extension of a euryhaline crab, Varuna litterata (Fabricius, 1798) (Brachyura: Varunidae), in a climate change hot-spot. Journal of Crustacean Biology, 37: 258-262.

Paulay, G. (1994) Biodiversity on Oceanic Islands: Its Origin and Extinction. American Zoologist, 34(1): 134-144.

Pecl, G. T., Araújo, M. B., Bell, J. D., Blanchard, J., Bonebrake, T. C., Chen, I.-C., Clark, T. D., Colwell, R. K., Danielsen, F., Evengard, B., Falconi, L., Ferrier, S., Frusher, S., Garcia, R. A., Griffis, R. B., Hobday, A. J., Janion-Scheepers, C., Jarzyna, M. A., Jennings, S., Lenoir, J., Linnetved, H. I., Martin, V. Y., McCormack, P. C., McDonald, J., Mitchell, N. J., Mustonen, T., Pandolfi, J. M., Pettorelli, N., Popova, E., Robinson, S. A., Scheffers, B. R., Shaw, J. D., Sorte, C. J. B., Strugnell, J. M., Sunday, J. M., Tuanmu, M.-N., Vergés, A., Villanueva, C., Wernberg, T., Wapstra, E. \& Williams, S. E. (2017) Biodiversity redistribution under climate change: Impacts on ecosystems and human well-being. Science, 355 .

Pouilly, M., Barrera, S. \& Rosales, C. (2006) Changes of taxonomic structure of fish assemblages along an environmental gradient in the Upper Beni watershed (Bolivia). Journal of Fish Biology, 68(1): 137-156.

Purvis, A., Gittleman, J. L., Cowlishaw, G. \& Mace, G. M. (2000) Predicting extinction risk in declining species. Proceedings of the Royal Society of London Series B: Biological Sciences, 267(1456): 1947-1952.

Rastetter, E. B., McKane, R. B., Shaver, G. R. \& Melillo, J. M. (1992) Changes in C storage by terrestrial ecosystems: How $\mathrm{CN}$ interactions restrict responses to $\mathrm{CO} 2$ and temperature. In: Natural Sinks of CO2. Springer, Dordrecht, pp. 327-344.

Richard, J. \& Chandran, M. R. (1994) A systematic report on the fresh water prawns of the atyid genus Caridina H. Milne Edwards 1837, from Madras (Tamilnadu: India). Journal of the Bombay Natural History Society, 91: 241-259.

Richard, J. \& Clark, P. F. (2005) Caridina nilotica (P. Roux, 1833) (Crustacea: Decapoda: Caridea: Atyidae) from East Africa, with descriptions of four new species. Proceedings of the Biological Society of Washington, 118(4): 706-730.

Richard, J. \& Clark, P. F. (2009) African Caridina (Crustacea: Decapoda: Caridea: Atyidae): redescriptions of C. africana Kingsley, 1882, C. togoensis Hilgendorf, 1893, C. natalensis Bouvier, 1925 and C. roubaudi Bouvier, 1925 with descriptions of 14 new species. Zootaxa, 1995: 1-75. 
Rosenblatt, A. E. \& Schmitz, O. J. (2016) Climate change, nutrition and bottom-up and top-down food web processes. Trends in Ecology and Evolution, 31(12): 965-975.

Saito, M., Yamashiro, T., Hamano, T. \& Nakata, K. (2012) Factors affecting distribution of freshwater shrimps and prawns in the Hiwasa River, southern Japan. Crustacean Research, 41:27-46.

Short, J. W. (2009) Freshwater Crustacea of the Mimika Region, New Guinea. PT Freeport Indonesia, Kuala Kencana, Timika (96p).

Staudt, A., Leidner, A. K., Howard, J., Brauman, K. A., Dukes, J. S., Hansen, L. J., Paukert, C., Sabo, J. \& Solorzano, L. A. (2013) The added complications of climate change: understanding and managing biodiversity and ecosystems. Frontiers in Ecology and the Environment, 11(9): 494-501.

Sterner, R. S. \& Elser, J. J. (2002) Ecological stoichiometry: the biology of elements from molecules to the biosphere. Princeton University Press, Princeton (NJ), USA.

Vaquer-Sunyer, R. \& Duarte, C. M. (2008) Thresholds of hypoxia for marine biodiversity. Proceeding of the National Academy of Sciences, 105(40): 15452-15457.

Veron, J. E. N., Devantier, L. M., Turak, E., Green, A. L., Kininmonth, S., Stafford-Smith, M. \& Peterson, N. (2009) Delineating the Coral Triangle. Galaxea, Journal of Coral Reef Studies, 11(2): 91-100.

Willig, M. R., Kaufman, D. M. \& Stevens, R. D. (2003) Latitudinal gradients of biodiversity: Pattern, Process, Scale, and Synthesis. Annual Review of Ecology, Evolution, and Systematics, 34(1): 273-309.

Wittmann, A. C. \& Pörtner, H. O. (2013) Sensitivities of extant animal taxa to ocean acidification. Nature Climate Change, 3(11): 995.

\section{Figures captions:}

Figure 1. Schematic representation of the different freshwater habitats. 1: Spring zone; 2: Higher course; 3: Waterfall; 4: Middle course; 5: Lower course; 6: Estuary; 7: Lake; 8: Swamp; 9: Subterranean waters.

Figure 2. Examples of habitats types. A: Higher course riffle, lotic mode (River Poitete, Kolombangara Island, Solomon Islands, credit PK); B: Higher course pool, lentic mode (Ciu waterfall, New Caledonia, credit VM); C: Middle course, lentic mode (River Wénou, New Caledonia, credit VM); D: Middle course riffle, lotic mode (River Nekouri, New Caledonia, credit 
638 VM); E: Lower course, lentic mode (River Hienghène, New Caledonia, credit VM); F: Lower 639 course riffle, lotic mode (River Negropo, New Caledonia, credit VM); G: Mangrove estuary (River 640 Tanghène, New Caledonia, credit VM); H: Estuary, low tide (Nera estuary, New Caledonia, credit 641 VM); I: Mountain stream (Unnamed tributary of the river Ciit, New Caledonia, credit VM); J: 642 Waterfall (Colnett waterfall, New Caledonia, credit VM); K: Swamp (Plaine des Lacs, New 643 Caledonia, credit VM); L: Lake (Lac en Huit, New Caledonia, credit VM).

644 Figure 3. Distribution area of Caridina.

645 Figure 4. Heat maps representing the species richness by locality. A: numbers of amphidromous 646 species (eggs $<0.8 \mathrm{~mm})$; B: numbers of landlocked species (eggs $>0.8 \mathrm{~mm}$ ); C: numbers of endemic 647 species (known from a single locality/area). 